IZA DP No. 6800

Global Pension Systems and Their Reform: Worldwide Drivers, Trends, and Challenges

Robert Holzmann

August 2012 


\title{
Global Pension Systems and Their Reform: Worldwide Drivers, Trends, and Challenges
}

\author{
Robert Holzmann \\ $\mathrm{RH}$ Institute for Economic Policy Analysis, \\ University of Malaya, IZA, CESifo and World Bank
}

Discussion Paper No. 6800

August 2012

IZA

P.O. Box 7240

53072 Bonn

Germany

Phone: +49-228-3894-0

Fax: +49-228-3894-180

E-mail: iza@iza.org

Any opinions expressed here are those of the author(s) and not those of IZA. Research published in this series may include views on policy, but the institute itself takes no institutional policy positions.

The Institute for the Study of Labor (IZA) in Bonn is a local and virtual international research center and a place of communication between science, politics and business. IZA is an independent nonprofit organization supported by Deutsche Post Foundation. The center is associated with the University of Bonn and offers a stimulating research environment through its international network, workshops and conferences, data service, project support, research visits and doctoral program. IZA engages in (i) original and internationally competitive research in all fields of labor economics, (ii) development of policy concepts, and (iii) dissemination of research results and concepts to the interested public.

IZA Discussion Papers often represent preliminary work and are circulated to encourage discussion. Citation of such a paper should account for its provisional character. A revised version may be available directly from the author. 
IZA Discussion Paper No. 6800

August 2012

\section{ABSTRACT}

\section{Global Pension Systems and Their Reform: Worldwide Drivers, Trends, and Challenges*}

Across the world, pension systems and their reforms are in a constant state of flux driven by shifting objectives, moving reform needs, and a changing enabling environment. The ongoing worldwide financial crisis and the adjustment to an uncertain "new normal" will make future pension systems different from past ones. The objectives of this policy review paper are threefold: (i) to briefly review recent and ongoing key changes that are triggering reforms; (ii) to outline the main reform trends across pension pillars; and (iii) to identify a few areas on which the pension reform community will need to focus to make a difference. The latter includes: creating solutions after the marginalization or, perhaps, demise of Bismarckian systems in countries with high rates of informality; keeping the elderly in the labor market; and addressing the uncertainty of longevity increases in pension schemes.

JEL Classification: $\quad$ G23, H55, I3, J21, J26

Keywords: population aging, longevity, financial crisis, multi pillar pension systems, social pension, NDC, MDC

Corresponding author:

Robert Holzmann

8584 Hirschegg 177

Austria

E-mail: Robert.Holzmann@IZA.org

\footnotetext{
* The paper has profited from presentations in Washington, D.C., Vienna and Kuala Lumpur and comments and suggestions received, in particular from Mark Dorfman, David Robalino and Peter Rosner, and two anonymous referees, and from excellent editing by Amy Gautam. I am, of course, solely responsible for any remaining errors and gaps.
} 


\section{Introduction}

The outlook on global pension systems and their reforms since the early 1990s has changed markedly over time; the most recent reassessment is triggered by the ongoing global financial crisis and its implications for funded and unfunded pensions.

After the fall of the Iron Curtain and the move in Central and Eastern Europe from central planning to market economies, the future for pension systems for some experts and policy makers appeared bright and fairly certain once the initial crisis was overcome: transferring main parts of retirement income provisions from the public sector to the private sector (i) to address fiscal unsustainability and projected further population aging and (ii) to accelerate financial market development was expected to trigger higher economic growth to co-finance some of the transition costs. This policy vision emerged from various sources: the successful Chilean pension reform and similar reform attempts in Latin America; the seminal 1994 World Bank publication that proposed a multi-pillar pension scheme with a significant shift from publicly managed, unfunded defined benefit (DB) schemes to privately managed, fully funded defined contribution (DC) schemes (World Bank 1994); and general enthusiasm and optimism for more market and financial intermediation instead of public intervention. This policy vision caught on in many countries: between 1988 and 2008, twenty-nine countries followed Chile's example, with systemic reforms and establishment of a main funded pension pillar (Figure 1). Before the financial crisis hit, even more countries were poised for reform (e.g., Ukraine) and some will still do (e.g. Czech Republic).

The worldwide reassessment of the policy approach to pension system reform is broadly the result of three changes: a readjustment of objectives (such as a refocus on basic protection for the vulnerable elderly); moving reform needs (such as recognizing the urgency of addressing the effects of population aging and deferred retirement ages); and perceived and actual changes in enabling environments (such as more realistic views about the capacity of funded schemes to manage risks, the achievable rates of return, and the fiscal restrictions to finance transition deficits). This reassessment has led to reform reversals in a few countries (e.g., Argentina, Hungary, and Slovakia) and to temporarily or permanently reduced funded pillar contributions in others (e.g., Estonia, Latvia, and Poland), but not to a global rejection of the 
funding or the DC approach. The reassessment has strengthened the push for alternative or complementary reform approaches, such as Non-financial (or Notional) Defined Contribution (NDC) and Matching Defined Contribution (MDC) schemes. While these new approaches should help move pension systems towards greater coverage and sustainability, there are a number of issues that still await solutions, such as addressing the uncertainty about longevity increases.

Against this background, the structure of this policy review paper is as follows: Section 2 briefly reviews recent and ongoing changes that have triggered a reassessment of pension systems and reform approaches; Section 3 outlines the main pension reform trends across pension pillars, and Section 4 proposes a few areas on which the pension reform community will need to focus to make a difference. The latter include: preparing solutions for implementation after the marginalization or, perhaps, even demise of Bismarckian schemes in countries with high informality; keeping the elderly in the labor market; and addressing longevity in pension products. A few pension fund-focused conclusions are presented in Section 5.

Figure 1: Evolution of number of countries with (mandated and funded) "Second pillars" as of 2008

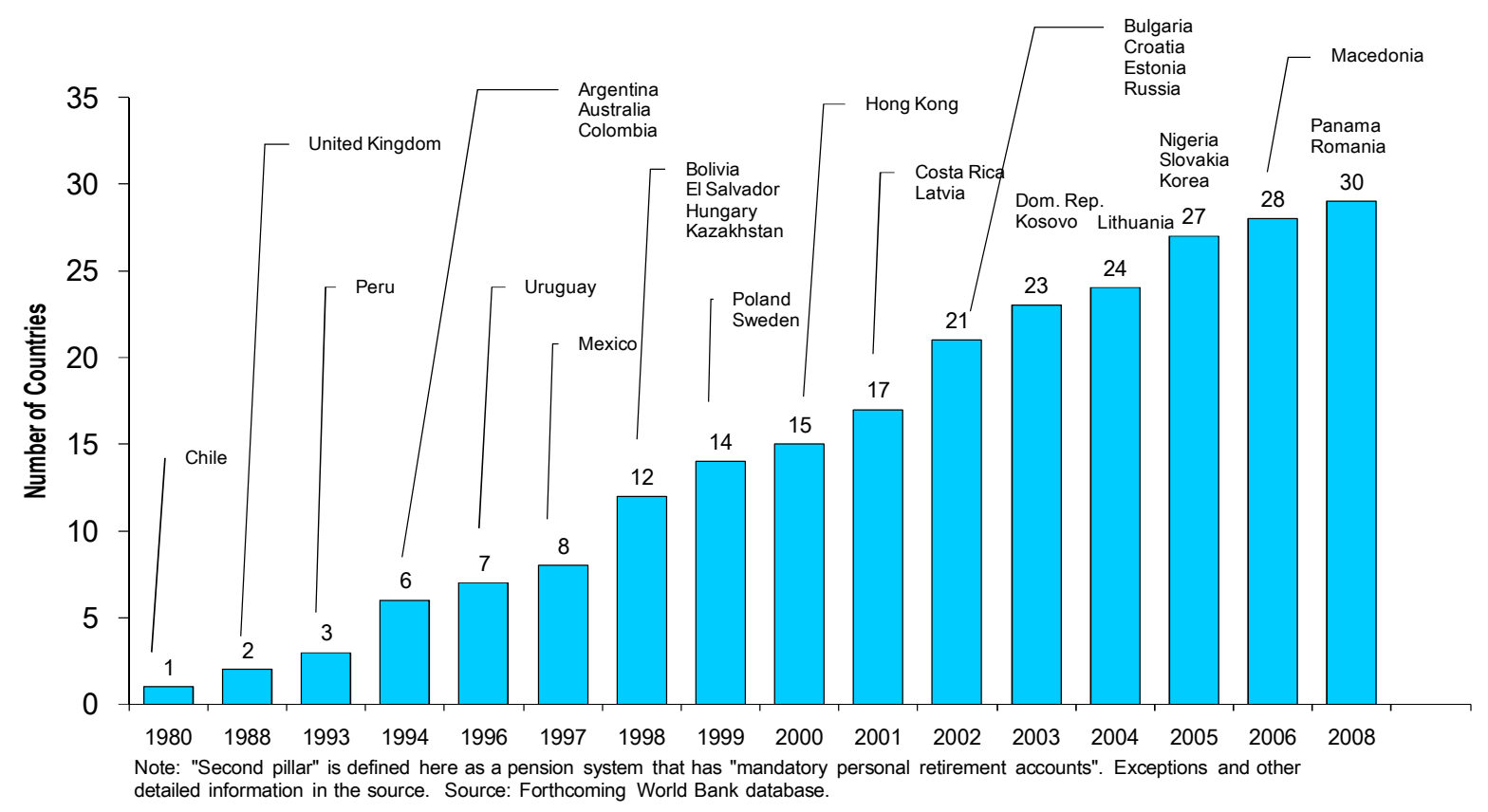

Source: World Bank Pension Data Bank. 


\section{Changes in Objectives, Reform Needs, and Enabling Environments}

Many changes are likely to have influenced the reassessment of what constitutes a good target for pension system reform (see Holzmann and Hinz 2005, Barr and Diamond 2008, and Orenstein 2011). In this section, four key changes are highlighted: the refocus on basic income protection for the elderly; the realization and implications of population aging; acknowledgment of lessons from the global financial crisis; and the re-assessment of achievable rates of return on pension fund assets.

\subsection{Refocusing on basic income protection for the elderly}

The refocus on basic income provisions for the vulnerable elderly across countries has three distinct but interrelated origins:

- Disappointment by pension reformers with coverage expansion after systemic pension reforms is quite likely the first main reason for redirected attention towards the vulnerable elderly and their income protection. For emerging economies, there were strong expectations that systemic pension reforms (at that time directed towards funded individual account systems) would contribute to a major increase in coverage/reduced informality as the contributionbenefit link tightened and credibility of the scheme increased, financial sectors developed and per-capita income grows. The coverage-per capita income link and a role for interventions is strongly suggested by cross country data (Chart 2). Yet, eight of eighteen countries in Latin America continue to have a pension coverage rate of the labor force below 30 percent, with only moderate improvements in some and largely un-systemic changes in most other countries over the last two decades (see Chart 3, and more in Rofman and Oliveri 2012). As a result, when reform and coverage expectations were not met, countries were forced to consider other approaches to extend coverage (as discussed in the next section).

- Reforms of earnings-related schemes towards a tighter contribution-benefit link limited the capability to redistribute income towards low income groups within the schemes. Furthermore, in high income countries, the coverage in contribution-based systems was being reduced due to lower contribution density, in part because of the difficult transitions into the labor market for 
youth, and because of the increasing mobility of workers between formal and informal wage employment and into self-employment, also in OECD countries (Holzmann 2003).

- The International Labour Organization (ILO), which had been sidelined in the discussion about multi-pillar pension reforms and funded pensions, returned with force to the international social policy arena, advocating a "social floor"; i.e., access to essential health care for all, and income protection for the elderly, the unemployed, and children (see ILO 2011). While implementation of basic old age income protection in many low and middle income countries is still awaiting realization, the political push has caught on in development circles.

Chart 2: The Coverage-Per Capita Income Connection (mid-late 2000s)

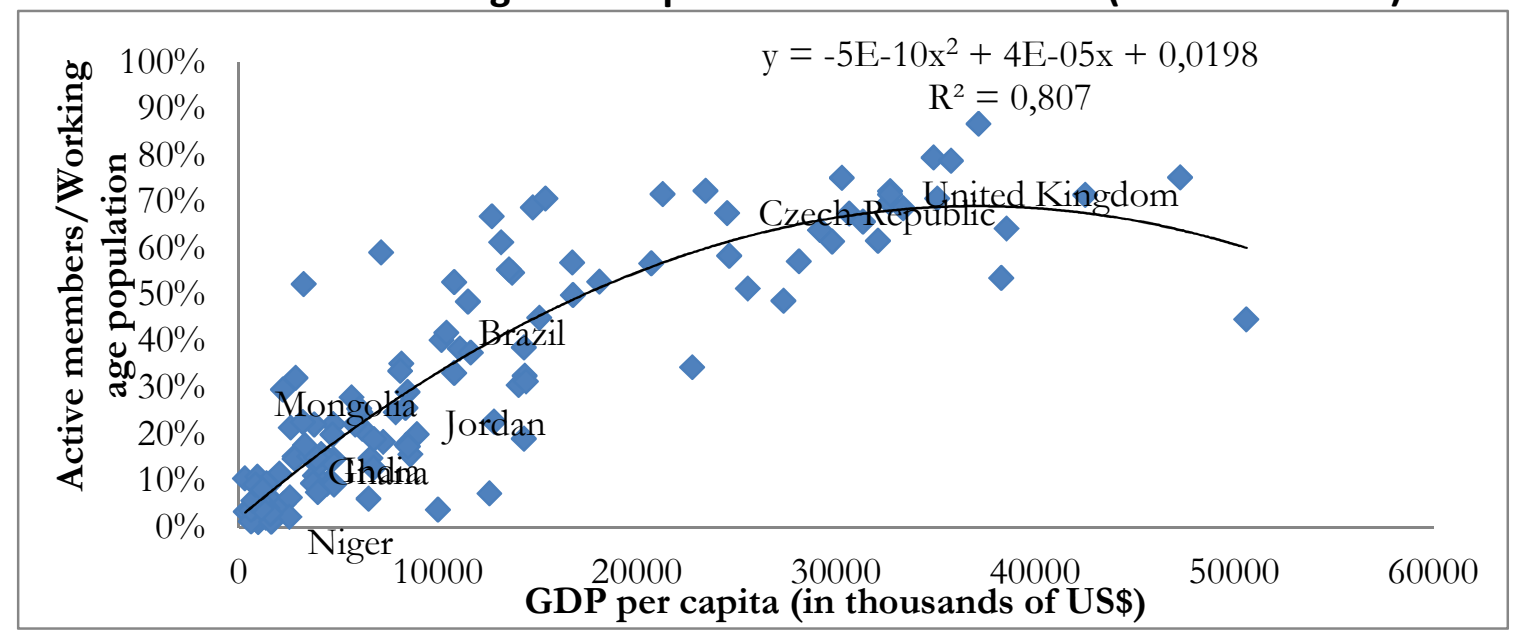

Source: World Bank Pension Data Base

Chart 3: Coverage of the Economically Active Population in Latin America (1990-2010)

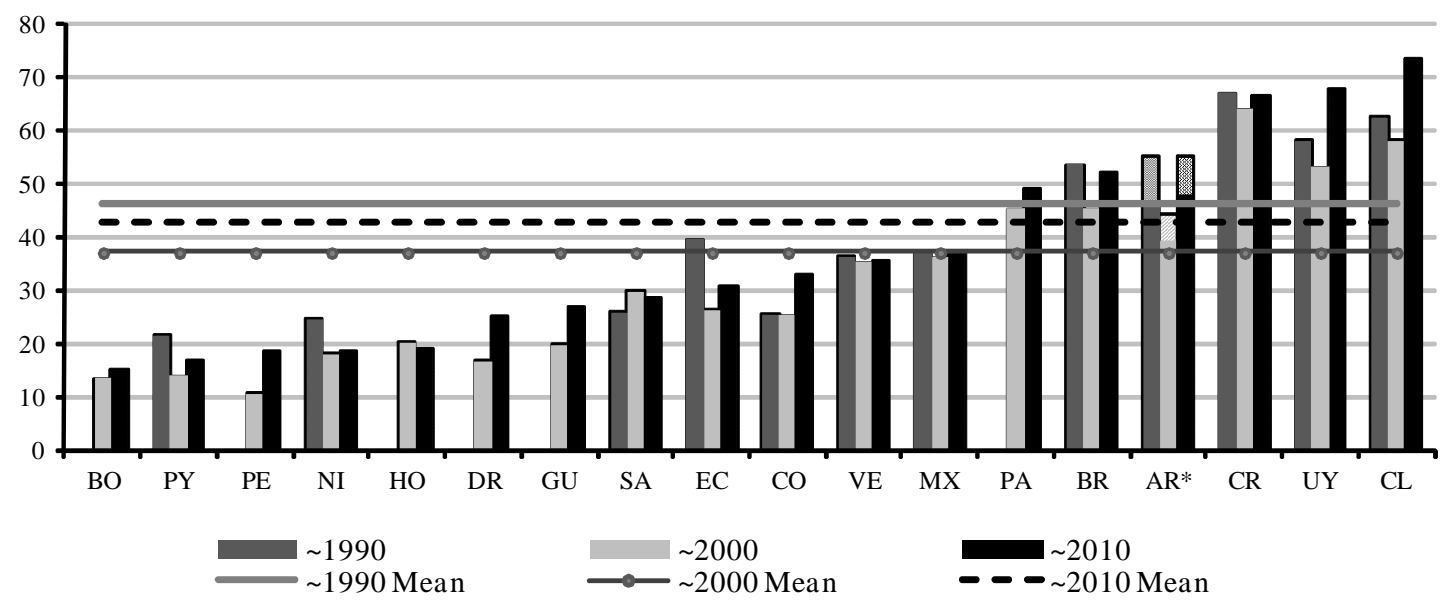

Source: Rofman and Oliveri (2012) 


\subsection{Realizing the implications of population aging}

Individuals and politicians in high income countries are finally waking up to the challenge of population aging. While the message of increased life expectancy, reduced fertility rates, and resultant deteriorating demographic (and system dependency) ratios has been around for some time, it has been largely ignored by politicians and the broader public until recently. Gradually, it has become clear that the effects of population aging on pension systems can only be addressed in three ways: higher contributions, lower benefits, or later retirement; and this applies to both unfunded and funded systems. Individuals and policy makers are also gradually acknowledging that the problem cannot be passed on to future generations, that higher contributions or lower benefits may not be the best approach, and that later retirement/working longer looks like the most natural and best solution. Yet it has also become better understood that simply legislating an increase in the legal retirement age may not be sufficient. Reforms of the pension system to provide incentives for later retirement and policies to keep the elderly in the labor market are required to raise the effective retirement age (see the recent White Paper by the European Commission 2012).

\subsection{Effects of the global financial crisis}

The financial, then economic, and now sovereign debt crisis that started in 2008 provides some sobering lessons for reformed pension systems which are only gradually being understood and translated into policy actions. Three lessons stand out in particular:

- The fall in GDP below the pre-crisis trajectory and in pension fund asset prices (not yet fully recovered in many countries) made a major dent in the financial situation of mandated pension schemes and individual benefit level, whether unfunded or funded. Under a severe crisis and low recovery scenario, the accumulated system deficits for the former transition economies in Central and Eastern Europe are projected in the low double digit percent of GDP (see Hinz et al. 2009). Yet the crisis impacts are still dwarfed by those associated with future population aging and the population effect is particularly strong in the former transition economies. The clear message is that more efforts must be undertaken, and more 
quickly, to address population aging and its effect on retirement schemes and public budgets if a future meltdown of pension systems is to be prevented (see IMF 2011).

- The budgetary consequences of the financial crisis render the financing of transition costs for a newly introduced funded pillar more difficult. Cash flow problems, already substantial on their own, are aggravated by the debt accounting under the Maastricht treaty, which takes insufficient account of the fact that with the reform, part of the increased explicit debt merely reflects a reduced implicit pension debt. These financing issues have been used by some countries as an excuse to legally (e.g., Argentina) or virtually (e.g., Hungary and Slovakia) end the funded pillar and to divert the pension fund assets for public debt reduction purposes. Other countries have implemented temporary (e.g., Estonia and Latvia) or permanent (e.g., Poland) reductions in the contribution rate to the funded pillar at the benefit of the unfunded pillar to reduce public deficit and debt (see World Bank 2009). While all reform countries were informed about the fiscal implications of a systemic pension reform, very few, if any, had a well thought-out plan for normal economic situations, let alone one for bad times.

- The temporary ${ }^{1}$ fall in asset prices and portfolio composition gave opponents of the systemic reform approach further ammunition (see Orenstein 2011). But it also led reform supporters to review some of the design components and to propose improvements, such as lifecycle portfolios (i.e., a mandated move from an aggressive to a more conservative portfolio as an individual approaches retirement, as is done in Chile), and more flexibility around mandated annuitization to avoid a locking-in of losses (see World Bank 2008).

\footnotetext{
${ }^{1}$ Albeit largely temporary, the situation had not fully recovered by the end of 2010 in OECD countries (OECD 2011b) while pension fund asset to GDP ratios in Asian Pacific countries by end-2010 are well above their 2007 levels (Hu 2012). For the latter this reflects both recoveries in asset prices as well as coverage expansion.
} 
Chart 3: Simulations of Fiscal Impact of Financial Crisis on Synthetic Country in Central and Eastern Europe
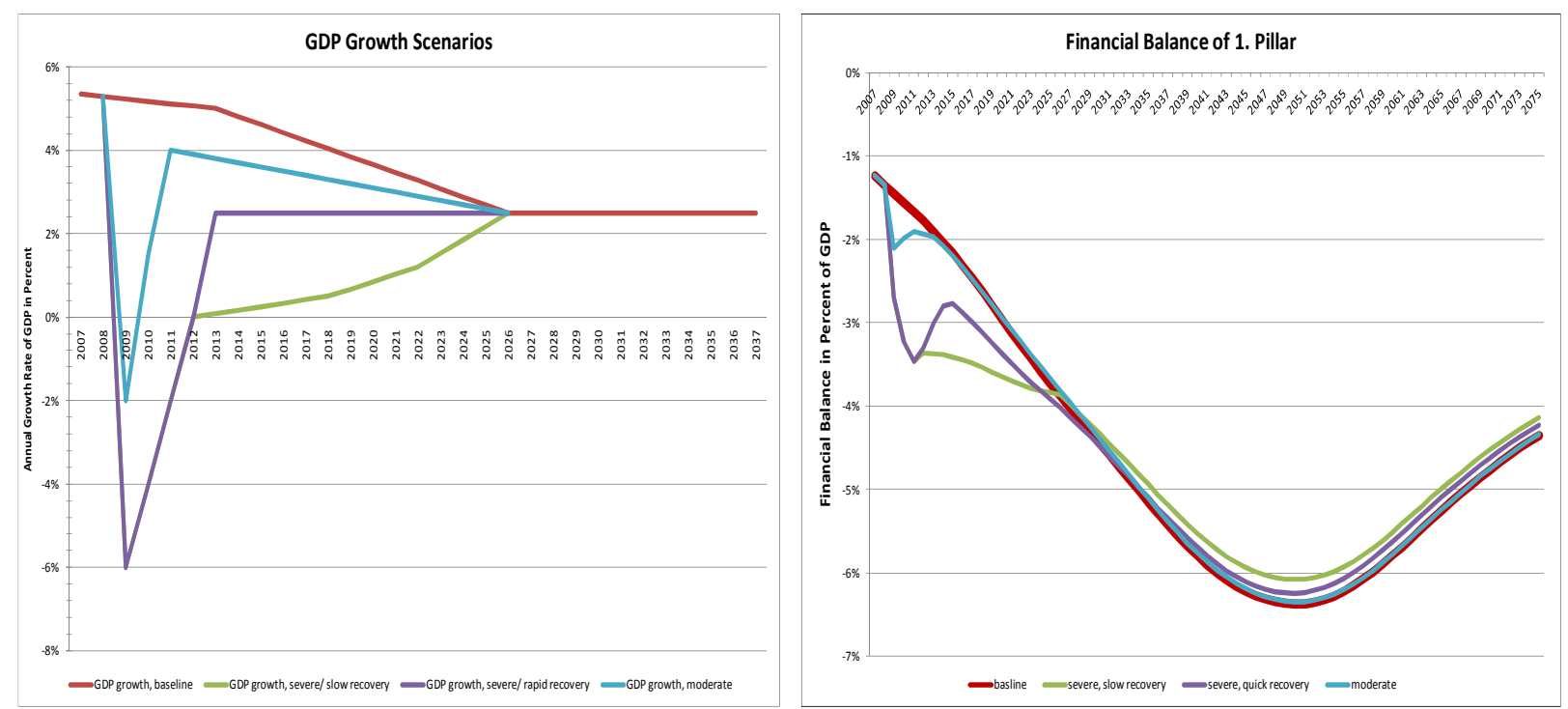

Source: Hinz et al. (2009)

Chart 4: Real Rates of Return (RoR) of Pension Funds in CEE before and during Crisis
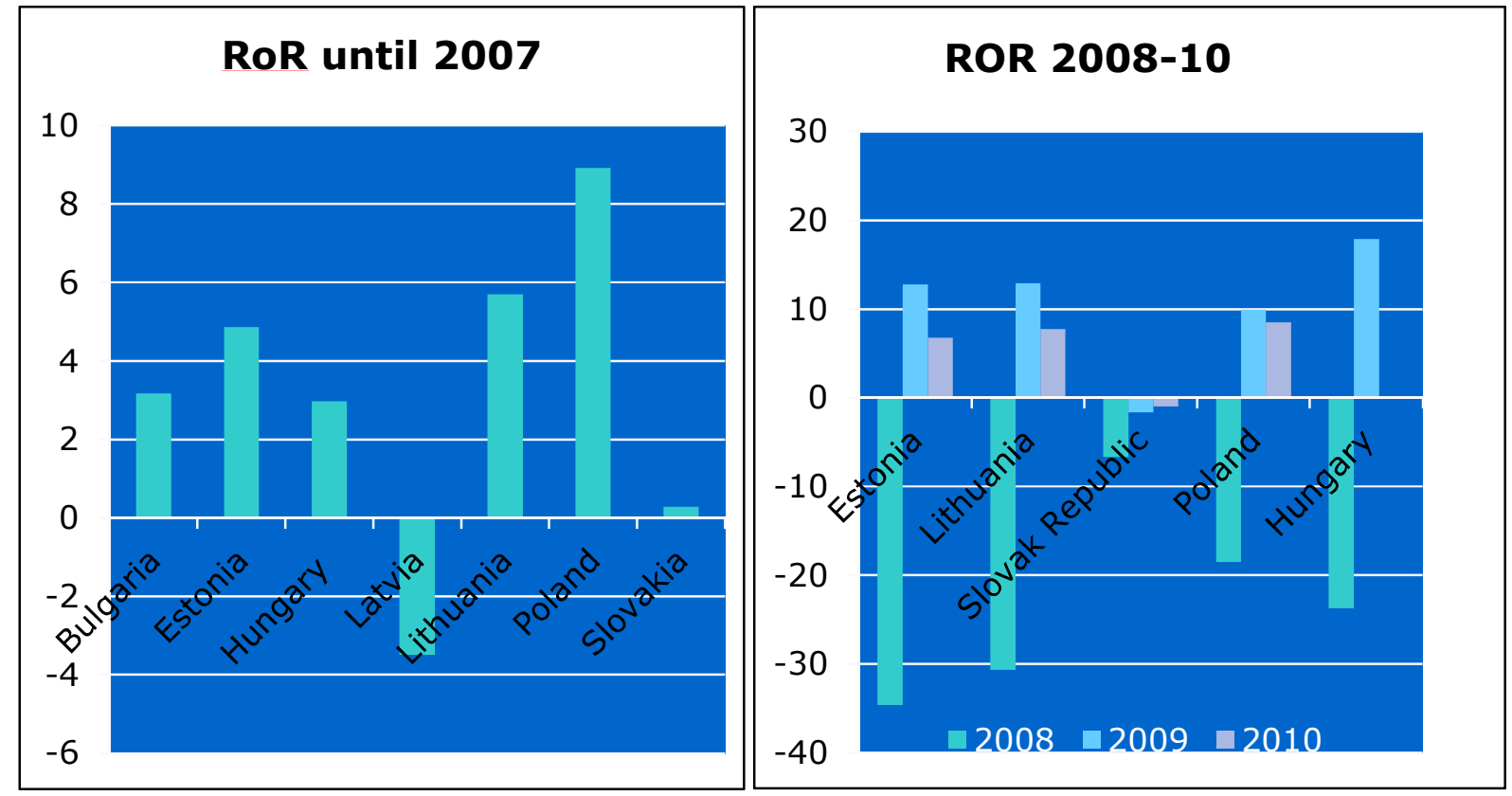

Source: OECD (2011b) 


\subsection{Rate of returns on assets}

The financial crisis of 2008 and beyond reinforced the already sober expectations for the rates of return of funded (and unfunded) schemes and increased uncertainty regarding regulatory reforms of pension funds (see IPE 2011). The high return expectations of the 1990s were first dampened by the bursting of the dot.com bubble in the early 2000s. The more recent and ongoing stark fluctuations in asset prices, the possible non-existence of an asset with zero risk (i.e., government bonds), and the likely "new normal" future of low real asset return for a protracted period of time create major uncertainties for individuals, policy makers and pension fund profession ${ }^{2}$; more critically, all this begs the question of the future of the size of funded pension pillars (compared to the unfunded pillars) and possibly even about their very existence. This question is additional to the still unanswered ones about the (international) performance of pension funds on a comparable basis and about how to usefully define such a basis (see Hinz et al. 2010). There is some recent evidence that even in countries like Chile the expected rates of return on financial assets may not necessarily surpass the growth rate of wages, which is the rate unfunded systems are able to pay (see Fajnzylber and Robalino 2012).

\section{Main Reform Trends across Pension Pillars}

The changes in objectives, reform needs, and enabling environments outlined in the prior section have a bearing on the reform trends across the world that can be highlighted through design and implementation innovations in the key pension pillars. The 2005 World Bank definitions and structure (Holzmann and Hinz 2005) are used; this structure separates a "zero pillar" from a "first public pillar" to better differentiate between the poverty reduction/redistributive (zero pillar) and consumption smoothing (first pillar) objectives of public and unfunded schemes. The second pillar refers to mandated funded schemes (DB or DC); the third pillar refers to voluntary funded schemes on an occupational or personal basis.

\footnotetext{
2 The uncertainty in the profession is visible by the topics of conferences (such as the 2012 Asian Pension Fund Round Table on "Managing Risks in a Deleveraging World") and publications that advise to see uncertainty as an opportunity (such as the recent 2012 Principals Global Investors publication on "Market Volatility: Friend or Foe").
} 
The fourth pillar offers informal (family), market-based, and public support (e.g., health care) to the elderly that impacts the scope and design of the other pension pillars, and is not discussed herein.

Using the pillar structure to highlight reform trends is motivated by the very broad and increasing support for the multi-pillar pension concept. The structure can be viewed: as an ordering principle for analysis; as a means of risk diversification (with unfunded pillars allocating savings to the pay-as-you-go asset and funded pillars to financial assets); and as recognition that different pillars have varying degrees of importance for the key target groups in a population (e.g., formal sector workers, those employed in the informal sector, and the lifetime poor). For low and many middle income countries, the informal sector is by far the largest group.

Table 1 highlights the basic system architecture for the mandated pillars by World Bank regions. As can be seen, the large majority of countries rely on first pillar schemes (that can be Notional Defined Benefit (NDB), Notional Defined Contribution (NDC), and public DC/provident fund arrangements) and almost half have a zero pillar (100 percent of the twenty-four traditional OECD countries have a zero pillar). Only thirty-two countries have mandated and funded pillars, of which two have a DB structure (Iceland and the Netherlands); the rest have DC structures. The most drastic changes since 1990 is the more than doubling of countries with a zero pillar, the transformation of NDB to NDCs schemes in 8 countries, and the introduction of FDC schemes in 29 countries that mostly complemented and only rarely replaced NDB schemes.

Data in Pallares-Miralles, Romero and Whitehouse (2012) also reveals that in 2011, the majority of countries (sixty) were still operating a separate scheme for civil servants, albeit some progress has been made in recent years to integrate these workers into the general scheme. 
Table 1: Basic system architecture by region, 2011 (and 1990)

\begin{tabular}{|c|c|c|c|c|c|c|c|}
\hline & \multicolumn{2}{|c|}{ Pillar 0} & \multicolumn{3}{|c|}{ Pillar 1} & \multicolumn{2}{|c|}{ Pillar 2} \\
\hline & Targeted & Basic & NDB & NDC & $\mathrm{PF}$ & FDC & FDB \\
\hline East Asia \& Pacific & 4 & 3 & 8 & 1 & 10 & 1 & 0 \\
\hline Europe \& Central Asia & 11 & 4 & 28 & 5 & 0 & 15 & 0 \\
\hline High income: OECD & 8 & 9 & 16 & 2 & 0 & 3 & 3 \\
\hline Latin America \& Caribbean & 16 & 2 & 29 & 0 & 0 & 9 & 0 \\
\hline Middle East \& North Africa & 1 & 1 & 17 & 0 & 0 & 0 & 0 \\
\hline South Asia & 3 & 0 & 2 & 0 & 3 & 1 & 0 \\
\hline Sub-Saharan Africa & 3 & 2 & 30 & 0 & 4 & 2 & 0 \\
\hline 2011 Total & 46 & 21 & 130 & 8 & 17 & 31 & 3 \\
\hline Grand Total & \multicolumn{2}{|c|}{67} & \multicolumn{3}{|c|}{155} & \multicolumn{2}{|c|}{34} \\
\hline 1990 Total & 20 & 10 & 140 & 0 & 17 & 2 & 3 \\
\hline Grand Total & \multicolumn{2}{|c|}{30} & \multicolumn{3}{|c|}{157} & \multicolumn{2}{|c|}{5} \\
\hline
\end{tabular}

Notes: NDB/NDC: Notional Defined Contribuition Scheme; FDC/FDB: Financial DC or DB scheme; PF: Provident Fund Source: Pallares-Miralles, Romero and Whitehouse 2012, and author.

\subsection{Zero pillar}

The main objective of the zero pillar is poverty reduction, and as this has become the focus of development policy, its importance has increased over the past two decades (Bloom and McKinnon 2012). In its simplest form, it is part of the social safety net that protects poor and vulnerable individuals of all ages through universal, means-tested, or conditional cash transfers; these instruments have been the revolution in low and middle income countries over the last decade (see Grosh et al. 2008). In the more "ear-marked" form of social pensions, zero pillar schemes provide income transfers to the elderly, typically via means-testing for the younger old people, and at times without means-testing for the very elderly. These schemes are now ubiquitous in traditional OECD member countries, and are increasingly but slowly gaining traction in low and middle income countries. An important step to integrate the new zero pillar with the earnings-related (funded) pillar took place in Chile in 2008; this reform is seen as a benchmark (see Rofman, Fajnzylber and Herrara 2008). There are also recent initiatives to implement ex ante transfers in the form of matching contributions for informal wage employment workers and the self-employed (discussed further below). Chart 5 offers a 
taxonomy of the retirement income transfers, including the guarantee of minimum pensions within the mandated (first or second) pillar.

\section{Chart 5: Taxonomy of First Pillar Retirement Income Transfers}

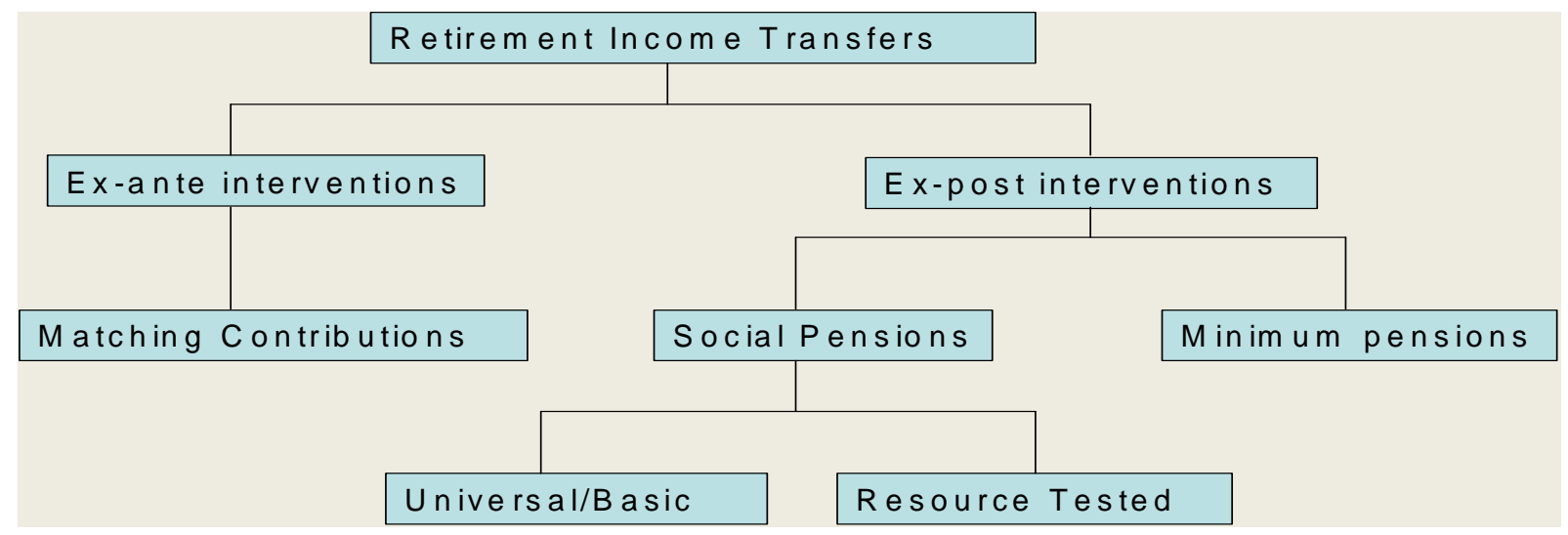

Source: Holzmann, Robalino and Takayama (2009)

The key questions about the zero pillar have changed little but a few new ones have been added. For low and middle income countries, the fiscal affordability, disincentive effects, and administrative issues of universal benefits compared to means-tested approaches remain an evergreen. New to the discussion is the potential role of ex ante interventions to address poverty and adequacy issues upstream, and the impact of social pensions on informality and thus coverage under formal earnings-related schemes (discussed below).

\subsection{First pillar}

The typical mandated, unfunded, and DB-type first public pillar has undergone reforms to various degrees across rich and poor countries. In OECD countries, reforms have been mostly parametric, and have included: a reduction in generosity (such as a lower annual accrual rate); lengthening of the assessment period at times to all contribution periods; the introduction of decrements for earlier and increments for later retirement; and in a number of countries, an increase in the standard retirement age (see OECD 2011a and 2012). Although all of these measures should ensure that the first pillar is sustainable, this seems to have been achieved in some, but not many, countries. In most countries, further parametric reforms are needed to address both population aging-related fiscal as well as labor market- and social policy-related 
incentive concerns. The challenge here is to deal with the political discretion that surrounds this type of reform and compromises the long-term solvency of pension schemes.

Against this background, the NDC scheme, a systemic reform innovation that maintains the unfunded character of the public first pillar, is attracting increasing attention in Europe and worldwide. The NDC scheme operates as a DC scheme in accumulation and annuity calculation at retirement, but remains unfunded (except for, perhaps, a reserve fund to address short-term liquidity issues). To achieve solvency, the NDC scheme offers only the notional rate of return that keeps the system solvent and only the annuity amount that is consistent with the remaining (projected cohort) life expectancy at retirement.

This pension reform innovation was introduced in the second half of the 1990s in Italy, Latvia, Poland, and Sweden and has weathered the financial crisis fairly well (see Chloń-Domińczak, Franco and Palmer 2012). In 2009, Norway legislated a reform now under implementation that mimics many but not all of the NDC features. In 2010, Egypt legislated an NDC reform for which implementation is envisaged for 2013. This reform approach is also under discussion in many EU countries, as well as in countries such as Belarus, China, Lebanon, and Uruguay.

The attractions of the NDC scheme are: the promised solvency even during adverse economic times and under severe population aging; the DC-type incentive structure to address labor market concerns and broader social changes (such as increasing life expectancy and rising divorce rates); and the openness to future partial or full shifts towards Funded Defined Contributions (FDC) schemes once the enabling environment has been created. While promising, the NDC approach is not foolproof, i.e. immune against policy mistakes, and a there are still a few conceptual and operational issues that have not yet been satisfactorily solved, such as the design of an effective balancing mechanism, including the measurement of assets and liabilities; the interactions of NDC schemes with other pillars and benefits (e.g., disability and survivor); reliable methods to project cohort life expectancy and equitable approaches for sharing the longevity risks; and defining and establishing the enabling environment for NDC implementation in low and middle income countries (see the recent anthology on NDCs by Holzmann, Palmer and Robalino 2012). 


\subsection{Second pillar}

The mandated and funded DC pillar has been the main innovation in pension reform design since it was introduced in Chile in 1981. While the Chilean reform is considered the most successful benchmark worldwide, very few of the other twenty-nine countries that had introduced second pillars as of 2008 have closely copied its design and implementation; in Europe and Central Asia, only Poland has done so. This may explain some of the variance in outcomes. Other than Chile, no country has conducted such a rigorous analytical evaluation of its second pillar scheme, or introduced reforms to improve existing structures (e.g., introduction of lifecycle funds or an integrated "solidarity pillar," or measures to reduce costs and fees) based on thorough analysis.

Consequently, many of the smaller and larger changes in countries with systemic reforms represent experimental corrections meant to address issues as they emerged. Three are highlighted:

- The high costs and fees of funded pensions have been a concern since the beginning, as their size presents a major reduction of the future benefit level. Fees amounting to 100 or more basis points lead to a reduction in ultimate benefits of 20 percent and more. Attempts to control costs and fees include: limits and caps; constraints on marketing efforts; innovative differentiated fee limits to create a contestable market; and the creation of clearing houses linked with blind accounts to reduce administrative and marketing costs, and to limit pension funds to an asset management function. While broadly moderately effective, these attempts have not been successful in limiting cost and fees to basis points in the low double digits. And there are conceptual considerations that the current approaches will never be able to meet given the production technology and information asymmetry involved; industrial organization models and investment products are suggested to make it work (see Impavido, Lasagabaster and García-Huitrón 2010).

- At their initiation, pension funds were typically subjected to a "Draconian regime" to avoid early mishaps and a discrediting of the reform approach. Tight regimes included quantitative restrictions on asset classes in which the pension fund could invest. Over time, 
the restrictions were relaxed, and in advanced countries, even abandoned. Concurrently, the financial significance of pension funds increased, making them a critical component of the financial market, on par with banks and insurance companies. This led to the extension of risk-based supervision methods, developed originally for bank supervision, to pension funds in a number of developed economies (such as Australia, Denmark, and the Netherlands) but also in emerging economies (such as Mexico). The different approaches applied provide a rich set of information for followers in both emerging and developed countries (see Brunner, Hinz and Rocha 2008).

- Much of the focus on the development of the second pillar in emerging economies in Latin America and Central and Eastern Europe was on the accumulation phase, as the payout phase was not to happen for many years. Yet the payout phase has almost arrived and the reform countries that introduced a second pillar now face the challenge of organizing the payout for retiring workers. This effort entails introducing a well-organized and wellsupervised market for retirement products, including marketing activities, and intermediaries. Alternatively, governments could provide the annuity in exchange for handing over the accumulated resources (as is done in Sweden). While some advanced economies (and Chile) provide useful lessons for the structure and operations of annuity markets (see Rocha, Vittas and Rudolph 2011), the features and trade-offs for key products are still little known (Vittas 2011), and financial assets to address inflation and longevity risks are not available (as discussed in the next section).

\subsection{Third pillar}

Establishment of this pillar of occupational or personal voluntary funded pensions has often preceded the creation of the mandated second pillar, but how best to regulate and supervise these schemes remains a challenge across the world. However, this pillar is receiving increasing levels of interest from policy makers everywhere as a means to offer some coverage to those employed in the informal sector in low and middle income countries, and to offer individuals an opportunity to compensate for reduced public generosity with individual saving efforts in high income countries. The links between public generosity and voluntary pension coverage clearly 
exists for OECD economies (Chart 6). To motivate voluntary participation, countries are using ex ante subsidies in the form of matching contributions (hence, Matching Defined Contribution (MDC) schemes) and/or other nudging devices and advocacy, particularly for informal workers (see Palacios and Robalino 2009). The latter include implementing massive information campaigns and dramatically reducing transactions costs for enrolling and contributing through the use of mobile phones, such as in the Mbao program in Kenya (ISSA 2011).

MDC schemes are well known in the developed economies such as the U.S. (401k scheme), Germany (Rister pension), and New Zealand (Kiwi Saver) for supplementing public benefits. However, MDCs are also gaining traction in emerging economies such as India and China for offering basic benefit coverage. For example, China started pilot schemes for the rural population in 2009, an experiment that was extended to the urban population in 2011. Whether the expectations of these schemes can and will be met is under discussion and review (Hinz et al). This adds to the better known issues of third pillar coverage, such as high administrative costs, lack of good annuity products, and the role and scope of regulation.

\section{Chart 6: Coverage Rate under Voluntary Private Pensions versus Replacement Rate under Public Pension Schemes}

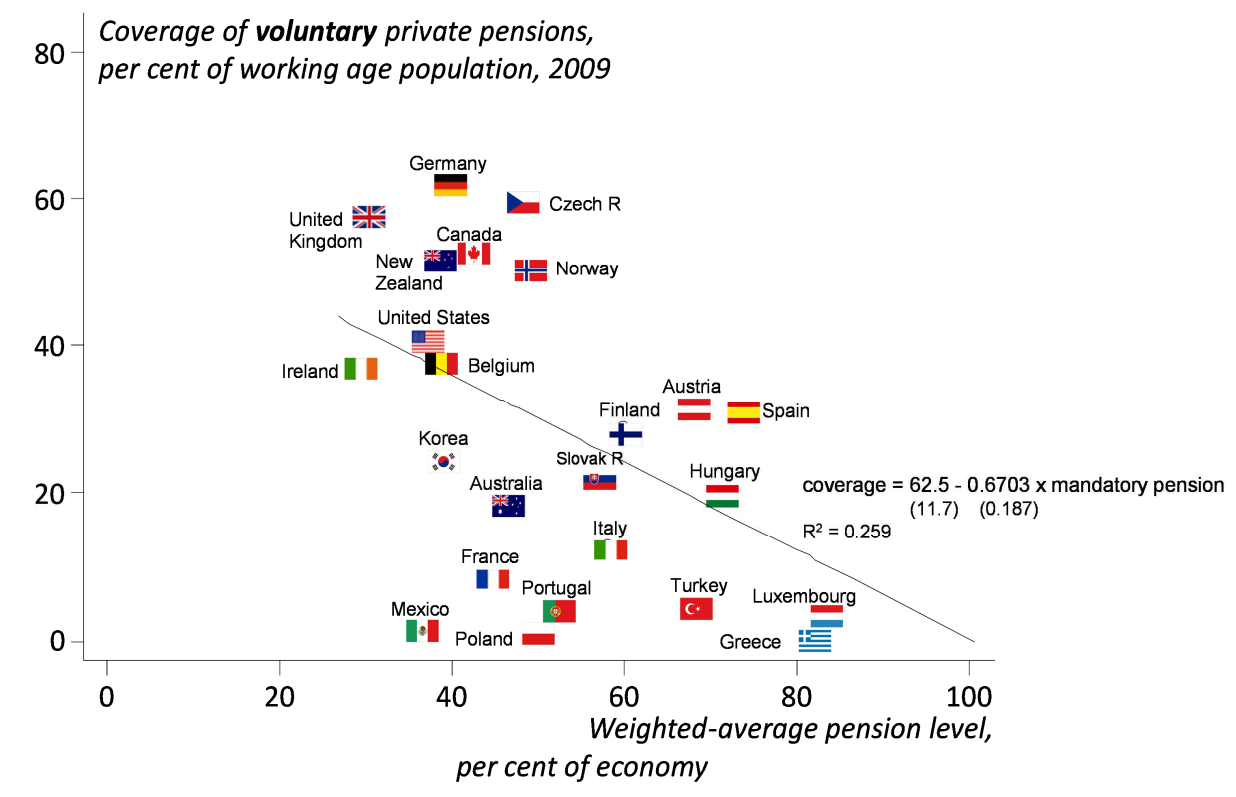

Source: Whitehouse, forthcoming. 
Overall, the move toward funded pensions through mandated (second pillar) or voluntary (third pillar) arrangements is visible in the size and growth of assets over the last decade for 13 major pension markets from US\$ 14.8 trillion to an estimated aggregate of US\$ 26.5 trillion by end2011; a record high if measured in absolute terms (Table 2). Pension assets in percent of GDP reached $72.3 \%$, still below the 2007 level of $78.9 \%$ but also below the 2010 ratio of $75.5 \%$. The crisis after 2007 left a dent in most but not all countries and regions that has not yet been recovered by end-2011 (Tower Watson 2012). Data for Asia Pacific signal higher ratios of pension assets to GDP in 2010 compared to 2007 in all 10 reviewed economies (Hu 2012).

Table 2: Pension Assets in 13 Major Pension Markets in end-2011

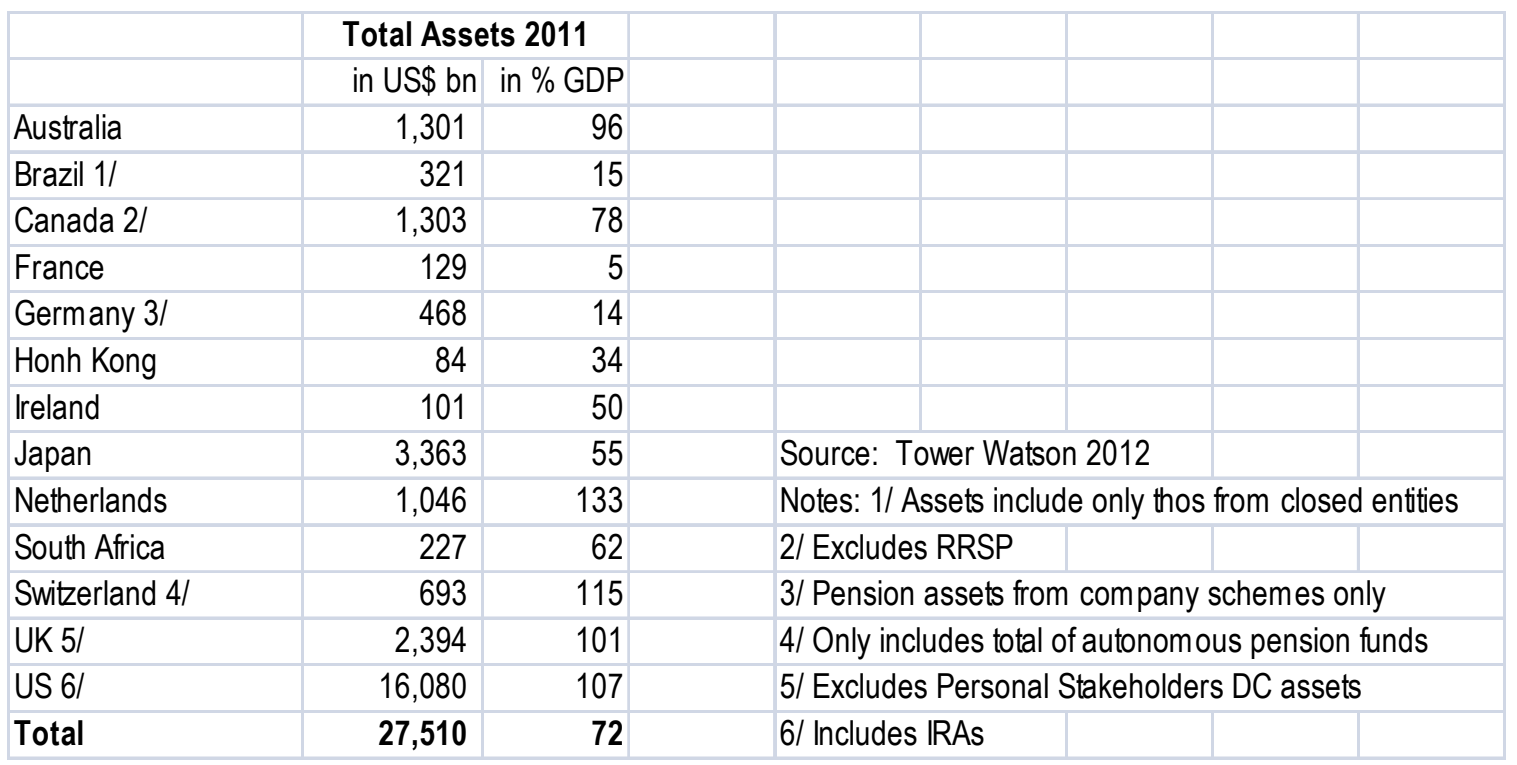

Source: Tower Watson 2012

\subsection{Centralized public pre-funding}

The trend to create and expand public pension reserve funds to support unfunded pillars, to more generally allow for intergenerational consumption smoothing, or to offer a societal cushioning against adverse future events expanded over the last decade to some eighteen OECD countries and a number of other major economies, such as China and Argentina. By the end of 2010, for OECD countries for which funds data are available, public pension reserve funds held US\$ 4.8 trillion (compared to US\$ 4.6 trillion in 2009; Table 3). Given the budgetary 
crises in many of these countries, it is doubtful that these funds will receive additional resources or even survive. The situation is likely to be different in resource rich countries with their earmarked reserve funds (such as in Australia and Norway) or in countries with sovereign wealth funds with a pension focus (such as in the Russian Federation). And among a number new resource rich developing countries in Asia (such as Kazakhstan and Mongolia), Latin America (such as Brazil following Chile's copper fund) and perhaps soon also some East and West African countries there is interest in creating wealth funds to address expected future shocks, including population aging. Such funds have a tradition in the oil-rich countries of the Gulf Cooperation Council.

Table 3: Size of public pension reserve fund markets in selected OECD countries and other major economies, 2010

\begin{tabular}{|c|c|c|c|c|c|}
\hline \multirow{2}{*}{ Country } & \multirow{2}{*}{ Name of the fund or institution } & \multirow{2}{*}{ Founded in } & \multicolumn{3}{|c|}{ Assets } \\
\hline & & & USD billions & $\%$ of GDP & $\%$ increase \\
\hline \multicolumn{6}{|c|}{ Selected OECD countries } \\
\hline United States & Social Security Trust Fund & 1940 & 2609.0 & 17.9 & 2.7 \\
\hline Japan (1) & Government Pension Investment Fund & 2006 & 1312.8 & 25.9 & n.d. \\
\hline Korea & National Pension Fund & 1988 & 280.4 & 27.6 & 16.7 \\
\hline Canada & Canadian Pension Plan & 1997 & 136.0 & 8.6 & 13.0 \\
\hline Sweden & National Pension Funds (AP1-AP4 and AP6) & 2000 & 124.7 & 27.2 & 8.1 \\
\hline Spain & Social Security Reserve Fund & 1997 & 85.3 & 6.1 & 7.3 \\
\hline France (1) & AGIRC-ARRCO & n.d. & 71.7 & 2.7 & n.d. \\
\hline Australia & Future Fund & 2006 & 65.8 & 5.5 & 8.4 \\
\hline France & Pension Reserve Fund & 1999 & 49.0 & 1.9 & 11.1 \\
\hline Ireland & National Pensions Reserve Fund & 2000 & 32.3 & 15.9 & 9.3 \\
\hline Belgium & Zilverfonds & 2001 & 23.3 & 5.0 & 4.3 \\
\hline Norway & Government Pension Fund - Norway & 2006 & 23.1 & 5.6 & 16.9 \\
\hline Portugal & Social Security Financial Stabilisation Fund & 1989 & 12.8 & 5.6 & 2.5 \\
\hline New Zealand (2) & New Zealand Superannuation Fund & 2001 & 11.2 & 7.9 & 17.1 \\
\hline Chile & Pension Reserve Fund & 2006 & 3.8 & 1.9 & 12.2 \\
\hline Mexico & IMSS Reserve & n.d. & 3.6 & 0.3 & -6.7 \\
\hline Poland & Demographic Reserve Fund & 2002 & 3.4 & 0.7 & 39.1 \\
\hline Total selected $\mathrm{OE}$ & D countries (3) & & 4848.1 & 19.6 & 5.0 \\
\hline \multicolumn{6}{|c|}{ Other major economies } \\
\hline Saudi Arabia & General Organisation for Social Insurance $(1,4)$ & 1969 & 400.0 & 106.4 & n.d. \\
\hline China & National Social Security Fund & 2001 & 126.5 & 2.2 & 10.3 \\
\hline Argentina & Sustainability Guarantee Fund & 2007 & 45.7 & 12.3 & 26.4 \\
\hline Total other major & conomies (3) & & 572.2 & 75.9 & 14.6 \\
\hline \multicolumn{6}{|c|}{ Memo item: Sovereign Wealth Funds with a pension focus (5) } \\
\hline Norway & Government Pension Fund - Global & 1990 & 509.1 & 122.8 & 16.6 \\
\hline Russian Federatic & National Wealth Fund & 2008 & 88.4 & 5.9 & -2.7 \\
\hline
\end{tabular}

Source: OECD (2011b) 


\section{Key Challenges Ahead}

There are many challenges ahead for pension systems, such as:

- Closing the coverage gap;

- Better integrating old age pensions with other insurance programs, in particular disability and survivor pensions, but also unemployment benefits and severance pay;

- Handling possibly lower future real rates of returns of funded schemes (seen as the "new normal" by some observers) as well as of unfunded schemes (due to projected lower or even negative labor force growth and lower productivity growth in aging economies) with conflicting views and empirical evidence;

- Finding innovative solutions for pension funds to invest abroad to tap into the conjectured higher capital productivity while reducing the savings constraints of low and middle income countries;

- Rethinking financing mechanisms away from contributions when funding legacy costs or redistributive components to reduce labor tax wedges and labor market distortions;

- Overcoming reform resistance, often conjectured to increase as the population ages and as the age of the median voter increases;

- Finding satisfying solutions for the full portability of acquired pension rights across professions, sectors, and countries for an increasingly internationally mobile labor force; and

- Elaboration concepts and defining best practices for reserve funds in resource rich and other countries as an integrated part of intergenerational and solvency considerations.

Section 4 highlights some of these challenges with three key questions: (i) will Bismarckian systems with their mandated and often high contribution rates survive in countries with high informality, and what happens after their marginalization or, perhaps, demise? (ii) how can the elderly be kept in the labor market?; and (iii) how can unknown longevity increases be addressed in the payout phase?

\subsection{Preparing for Bismarck's demise and succession}

As discussed above, to address low pension coverage, many low and middle income countries introduced basic provisions in the form of social pensions, still assuming that over time, workers would move towards formal sector employment and participation in a mandated and 
earnings-related (funded or unfunded) scheme. Yet in fact, these very provisions (essentially subsidies) risk becoming a tax on formal work and providing individuals with incentives to take informal jobs or move into self-employment while they build up their own retirement provisions (e.g., businesses, houses, financial assets, etc.), knowing that the safety net will be there for them if everything else fails. Such a tendency seems to be particularly pronounced in Latin America, as suggested by recent analytical work (see, e.g., Levy, 2008; Aterido, HallwardDriemeier and Pagés 2011; and Ribe, Robalino and Walker 2012). If confirmed, this may risk sounding the death knell of Bismarckian systems in many low and middle income countries. But what would a future retirement income scheme look like: Only basic provisions plus unstructured voluntary retirement provisions? Or innovative new schemes in which basic provisions are also based on individual accounts funded across the lifecycle by government and augmented by individual savings supplements of unknown design? Or? Stay tuned ...

\subsection{Keeping the elderly in the labor market}

There is a growing understanding and emerging consensus among many (but not yet all) policy makers in OECD economies that the solution to the aging problem is to be found in longer labor market participation and hence later retirement of individuals. Thus, there is a willingness to raise the legal retirement age as witnessed in many OECD countries (OECD 2011a and 2012). However, there is not yet full recognition that a legal decision alone will do little to raise the effective retirement age unless major reforms in the labor market take place to allow the elderly to remain productively employed and to provide employers with incentives to keep them employed/offer them jobs. While the basic ingredients are simple to pronounce (i.e., keep them healthy, skilled, and motivated), the policies to do so are less known or implementable across varying cultural contexts. And implementing successful reforms requires reviewing many or all of a country's institutions and regulations, including the incentive structure of the pension system. But unless workers are convinced that they will have a job when they are older, they are likely to oppose a legal increase in the retirement age. While OECD countries have started introducing promising reforms at the firm level to improve labor market opportunities for the elderly (see, e.g., European Centre for the Development of 
Vocational Training 2008), any scaling-up or translation to other countries is, for the time being, limited by the lack of sound analytical penetration and rigorous monitoring and evaluation of these innovations.

\subsection{Addressing unknown longevity increases during the payout phase}

Perhaps the main open design issue for both NDC and FDC schemes concerns the payout phase and how best to address shocks in longevity. The financial, social, and political sustainability of a DC scheme requires translating accumulated savings at retirement into an annuity that takes account of the projected remaining cohort life expectancy, and that has adjustment features that are fair and transparent if the longevity projections turn out to be wrong. At the moment, DC systems do not have reliable projection methods for mortality rates and remaining life expectancies (see, e.g., Alho, Bravo and Palmer 2012). Neither NDC nor FDC schemes have robust methods for distributing the risks if projection errors take place. In FDC schemes that typically use the private sector annuity market, the financial sector provider officially takes the risk, while individuals and/or the government bear the final risk if insurers go bankrupt, but with untested proportions. In NDC schemes run by the rule book, projection errors can be corrected by adjusting the notional interest rate and the annual indexation of pensions effectively distributing risks between active and retired plan members in specified proportions. For both FDC and NDC schemes, there are several proposals to address the longevity issue through longevity bonds that create an effective hedge against the longevity risks (see Blake, Boardman and Cairns 2010; Palmer 2012). These proposals need further analysis and piloting prior to full implementation, however. Across the world are financial market instruments to hedge longevity risks still virtually non-existent (Roy 2012). Whatever progress can be made in this area, paying attention to population aging and longevity issues forms part the reforms to increase the confidence in public and private sector balance sheets (IMF 2012).

\section{Concluding Remarks}

Pension systems are in constant flux, and their reforms are driven by shifting objectives, moving reform needs, and changing enabling environments. Over recent decades, this has led to a number of redirections and innovations throughout the world, including: the introduction or 
strengthening of basic protection for the vulnerable elderly; the move towards funded and unfunded mandated DC schemes; and increased nudging by governments to encourage benefit coverage and "top-ups" under voluntary and funded provisions.

The move towards pre-funded old age income provisions is now itself under review as fallout of the financial crisis/recession/borderline depression. Areas of concern include the fall in asset prices, the high fluctuations in the rates of return, and the possibility of lower real risk-adjusted rates of return as the "new normal." Some of the lessons from the crisis are straightforward and easy to implement, such as the move towards lifecycle funds. Others may be more difficult to deal with, such as the outlook to lower rates of return plus higher return rate volatility.

However, such a review is unlikely to ring the death knell of pre-funded old age pensions, if only for the simple reason that the fiscal conditions after the crisis and the fiscal implications of the expected further aging of populations limit both the capacity and the willingness of governments to take care of the whole retirement income task. However, providers of funded provisions will need to work hard to reestablish confidence and to deliver what is promised to keep their share in the retirement income market.

\section{References}

Aterido, Reyes, Mary Hallward-Driemeier, and Carmen Pagés. 2011. "Does Expanding Health Insurance Beyond Formal-Sector Workers Encourage Informality? Measuring the Impact of Mexico's Seguro Popular." IZA Discussion Paper No. 5996. Bonn: IZA.

Alho, Juha, Jorge Miguel Bravo, and Edward Palmer. 2012. "Annuities and Life Expectancy in NDC." In Holzmann, Palmer, and Robalino (eds), op cit. chapter 22.

Barr, Nicholas and Peter Diamond. 2008. Reforming Pensions: Principles and Policy Choices. Oxford University Press.et al.: Oxford.

Blake, David, Tom Boardman, and Andrew Cairns. 2010. "Sharing Longevity Risk: Why Governments Should Issue Longevity Bonds." Discussion Paper PI-1002. London: The Pensions Institute. Available at: pensions-institute.org/workingpapers/wp1002.pdf.

Bloom, David and Roddy McKinnon. 2012. The design and implementation of public pension systems in developing countries: Issues and options, mimeo. 
Brunner, Greg, Richard Hinz and Roberto Rocha. 2008. Risk-Based Supervision of Pension Funds: Emerging Practices and Challenges. Washington, DC: World Bank.

Chloń-Domińczak, Agnieszka, Daniele Franco and Edward Palmer. 2012. "The First Wave of NDC Reforms: The Experiences of Italy, Latvia, Poland and Sweden". In Holzmann, Palmer and Robalino (eds), op. cit. Volume I, chapter 2.

European Centre for the Development of Vocational Training. 2008. "Innovative Learning Measures for Older Workers." Cedefop Panorama Series, 159. Luxembourg: Office for Official Publications of the European Communities.

European Commission. 2012. An Agenda for Adequate, Safe and Sustainable Pensions. White Paper. Brussels: COM.

Fajnzylber, Eduardo and David Robalino, 2012. "Chile: Shadowing of FDC with NDC." In Holzmann and Palmer, eds. op cit. Chapter 9.

Grosh, Margaret, Carlo del Ninno, Emil Tesliuc, and Azedine Ouerghi. 2008. For Protection \& Promotion: The Design and Implementation of Effective Safety Nets. Washington, DC: World Bank.

Hinz, Richard, Asta Zviniene, Sergi Biletsky, Tatyana Bogomolova. 2009. "The Impact of the Financial Crisis on Public Pension Systems: Stress Testing Models of Mandatory Pension Systems in Middle Income and Developing Countries". Social Protection \& Labor Department. Washington, DC: World Bank. Mimeo, September.

Hinz, Richard, Heinz P. Rudolph, Pablo Antolin, and Juan Yermo. 2010. Evaluating the Financial Performance of Funds. Washington, DC: World Bank.

Hinz, Richard, Robert Holzmann, David Testa and Noriyuki Takayama, eds. forthcoming. Matching Defined Contribution (MDC) Schemes: A Promising Pension Design to Enhance Coverage and Benefit Level? Washington DC: World Bank.

Holzmann, Robert. 2003. A Provocative Note on Coverage in Public Pension Schemes, in: Tausch, A. (2003, ed.): The Three Pillars of Wisdom - A Reader on Globalization, World Bank Pension Models and Welfare Society, New York (Nova Science Publisher), 85-99.

Holzmann, Robert, Edward Palmer and David Robalino, eds. 2012. NDC Pension Schemes in a Changing Pension World, Volume 1: Progress, Issues, and Implementation; Volume 2: Gender, Politics, and Financial Stability. Washington, DC: World Bank and Swedish Social Insurance Agency.

Holzmann, Robert, David A. Robalino, and Noriyuki Takayama, eds. 2009. Closing the Coverage Gap - The Role of Social Pensions and Other Retirement Income Transfers. Washington, DC: World Bank. 
Holzmann, Robert and Edward Palmer, eds. 2006. Pension Reform: Issues and Prospect for NonFinancial Defined Contribution (NDC) Schemes. Washington, DC: World Bank. (also available in Chinese, German and Spanish).

Holzmann, R., Richard Hinz, and Bank Team. 2005. Old-Age Income Support in the Twenty-first Century: An International Perspective on Pension Systems and Reform. Washington, DC: World Bank (also available in Arabic, Chinese, Russian and Spanish).

Hu Yuwei. 2012. Growth of Asian Pension Assets: Implications for Financial and Capital Markets. ADBI Working Paper Series No. 360, May. Tokyo: ADBI.

International Labor Organisation (ILO). 2011. The Social Protection Floor. Geneva: ILO.

International Monetary Fund (IMF). 2011. The Challenge of Public Pension Reform in Advanced and Emerging Economies. Fiscal Affairs Department, December 28. Washington, DC: IMF

Impavido, Gregorio, Esperanza Lasagabaster, and Manuel García-Huitrón. 2010. New Policies for Mandatory Defined Contribution Pensions: Industrial organization models and investment products. Washington, DC: World Bank.

Investment \& Pensions Europe (IPE). 2011. "Top 1000 European Pension Funds." London: IPE International Publisher, October.

International Monetary Fund. 2012. "The Financial Impact of Longevity", in Global Financial

Stability Report: The Quest for Lasting Stability, Chapter 4. Washington, DC: International Monetary Fund, 135-165.

International Social Security Association (ISSA). 2011. Mbao Pension Plan: A case of the Retirement Benefits Authority. Good Practices in Social Security. Geneva: ISSA. www.issa.int

Levy, Santiago. 2008. Good Intentions, Bad Outcomes. Washington, DC: Brookings Institution.

OECD. 2011a. Pensions at a Glance 2011: Retirement-Income Systems in OECD and G20 Countries. Paris: OECD.

OECD. 2011b. "Pension Markets in Focus." Issue 8, July. Paris: OECD.

OECD. 2012. OECD Pension Outlook 2012. Paris: OECD.

Orenstein, Mitchell A. 2011. "Pension privatization in crisis: Demise or rebirth of a global policy trend?" International Social Security Review, vol. 64 (3): 65-80.

Palacios, Robert and David Robalino. 2009. "Matching Defined Contributions: A way to Increase Pension Coverage". In Holzmann, Robalino and Takayama, op. cit. Chapter 13: 187-202. 
Pallares-Miralles, Montserrat, Carolina Romero, and Edward Whitehouse. 2012. International Patterns of Pension Provision II: Worldwide Overview of Facts and Figures, Social Protection Discussion Papers No. 1212, May.

Palmer, Edward. 2012. "Generic NDC: Equilibrium, Valuation and Risk Sharing." In Holzmann, Palmer and Robalino (eds), op cit. chapter 19.

Ribe, Helena, David Robalino, and Ian Walker. 2012. From Right to Reality: Incentives, Labor Markets, and the Challenge of Achieving Universal Social Protection in Latin America and the Caribbean. Latin American Development Forum Series. Washington, DC: World Bank.

Rocha, Roberto, Dmitri Vittas, and Heinz P. Rudolph. 2011. Annuities and other Retirement Products: Designing the Payout Phase. Washington, DC: World Bank.

Rofman, Rafel, Eduardo Fajnzylber, and German Herrara. 2008. "Reforming the Pension Reforms: The Recent Initiatives and Actions on Pensions in Argentina and Chile." Social Protection Discussion Papers No. 0831, May. Washington, DC: World Bank.

Rofmann, Rafel and Maria Laura Oliveri. 2012. Pension Coverage in Latin America: Trends and Determinants. Social Protection Discussion Papers No. 1217, August.

Roy Amlan. 2012. Innovative Approaches to Managing Longevity Risk in Asia: Lessons from the West. ADBI Working Paper Series No. 360, May. Tokyo: ADBI.

Tower Watson. 2012. Global Pension Asset Study. TowerWatson.com.

Vittas, Dimitri. 2011. "The Mechanics and Regulations of Variable Payout Annuities." Policy Research Working Papers No. 5962, August. Washington, DC: World Bank.

Whitehouse, Eduardo. forthcoming. "Policies to Encourage Private Pension Savings: Evidence from OECD Countries", in Hinz et al., eds. Matching Defined Contribution (MDC) Schemes: A Promising Pension Design to Enhance Coverage and Benefit Level? Washington DC: World Bank.

World Bank. 1994. Averting the Old Age Crisis. Washington, DC: World Bank.

World Bank. 2008. "The Financial Crisis and Mandatory Pension Systems in Developing Countries: Short- and Medium-term Responses for Retirement Income Systems." Pension Reform Primer Notes, December. Washington, DC: World Bank.

World Bank. 2009. "Pensions in Crisis: Europe and Central Asia Regional Policy Note." Europe and Central Asia, November. Washington, DC: World Bank. 